
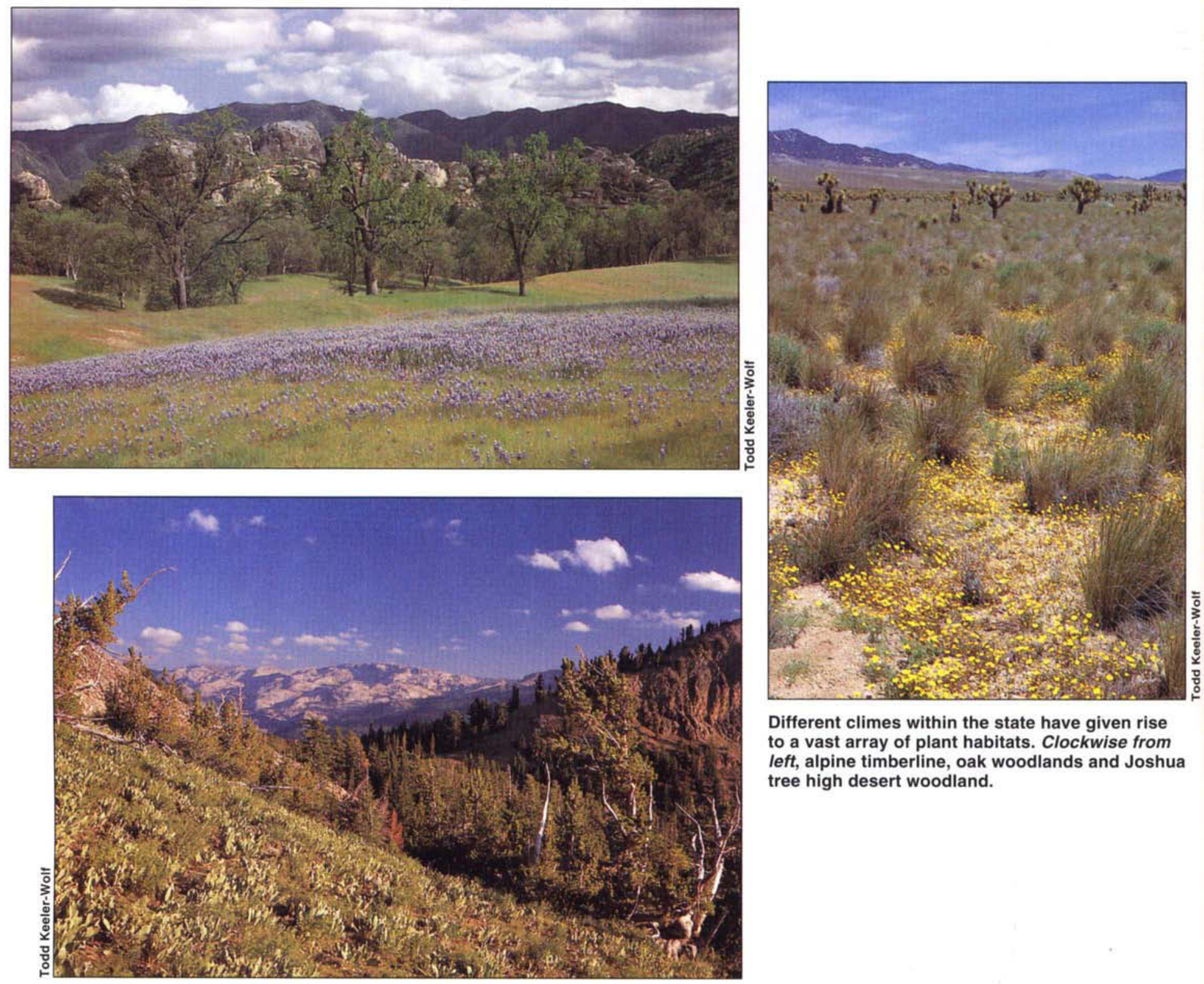

Different climes within the state have given rise to a vast array of plant habitats. Clockwise from left, alpine timberline, oak woodlands and Joshua tree high desert woodland.

\title{
Inventory first step to conserving plant diversity
}

Bruce M. Pavlik

\begin{abstract}
After 200 years of exploration and study, botanists have found California's native flora to be diverse and unique. Despite having great economic, scientific and aesthetic values, many species are close to extinction. Conserving the flora will require additional scientific efforts to catalog, map, preserve and restore diversity at the level of the gene, species and natural habitat.
\end{abstract}

Dublic discussions of biodiversity often focus on animals, especially the charismatic vertebrates we commonly associate with the words "wildlife" and "endangered species." Indeed, it is hard not to think of sea otters, spotted owls and fringe-toed lizards when the issues of environment and economy collide. Although the 742 native vertebrates found in our state certainly deserve conservation, they represent but one segment of California's biological inheritance.
The nearly 6,000 kinds of vascular plants native to California also require careful consideration when decisions are made regarding land use and development. Many of these plants are already of great importance to agriculture, forestry and the pharmaceutical industry, while others have yet to be exploited. Native trees, shrubs and herbs form essential habitats for most other life forms in the state, whether bacteria or butterflies or bears. But regardless of utility to man and beast, 
the California flora should be regarded as a world-class botanical treasure that is as unique and beautiful as the land of its origin.

We are now faced with the dilemma of how to preserve that treasure for future generations while encouraging economic expansion and undergoing rapid population growth. Unlike animals, plants cannot flee from a piece of land scheduled for development and often that piece of land contains the only remaining habitat that is suitable for a particular plant species. There are no simple solutions, but there have been great advances over the last quarter century in our understanding, management and appreciation of these irreplaceable resources.

\section{California flora - unique, diverse}

During his exploration of California in May of 1850, naturalist and artist J.W. Audubon wrote "I see daily new... plants that a year's steady work could not draw, but if our government would send good men, what a work of national pride could be brought out! Geology, botany, entomology, zoology, etc. The views are frequently superb, and the hemlocks and pines of many species most beautiful."

By then botanists had already been sending specimens of California's plants back to European academies for 60 years, but this is the earliest known expression of appreciation for the diversity of the state's flora as a whole, with an enthusiastic call for a scientific inventory on behalf of the nation's vital interests. Scientists did follow, sent with nearly every survey party and expedition, and they accelerated the pace of collecting, describing, and cataloging plant life in the west. Slowly, the experts began sorting through and naming the many species of lupines, buckwheats, oaks and sedges that are distinctively different from related species found elsewhere. Some of the plants were so different that botanists had to create new categories for classification. Coast redwood, fan palm, flannelbush, Catalina ironwood and many other California plants were set aside as whole new genera (Sequoia, Washingtonia, Fremontodendron, and
Lyonothamnus, respectively) that had been previously unknown to science.

In 1925 W.L. Jepson published the first comprehensive inventory of the California flora, a distillation based on 150 years' worth of specimens, field notes, expedition journals and scholarly publications. He carefully documented the occurrence of 3,727 native species known at that time, and compiled a list of 292 weed species from other parts of the world that had become established in California. Jepson saw the flora not only as a long list of interesting plants, but also as a rich, green quilt of species that were arranged into natural communities and that migrated and evolved across landscapes and geological time. But Jepson's visionary manual was not an end in itself: it launched an army of botanists who searched nearly every canyon, plain and mountain range in California to improve our understanding of the flora's origins, distribution and prospects for the future.

The most recent inventory of California's flora, a 1993 revision of the Jepson manual, reinforces the statement that California is a world center for plant diversity (table 1). The total native flora of 4,839 known species is larger than that of any state in the union, and larger than the floras of the northeast United States and all of Canada combined! Per unit area of land, there are two to 10 times as many species in California as anywhere else in temperate North America. Furthermore, $29 \%$ of those species are endemic to the state, which means that they are found nowhere else in the world. The manual also recognizes 1,159 native subspecies or varieties, most of which are also endemic to the state. So botanists can now say with both pride and authority that there are 5,998 kinds of plants native to California and approximately 2,153 kinds are endemic.

These three characteristics of California's plant life - the large number of species, the high density of species per unit area of land, and the high endemism - are usually associated with the diverse floras of tropical

TABLE 1. The richness of California's native flora is unsurpassed on the North American continent, and can even be compared to the floras of tropical islands*

\begin{tabular}{|c|c|c|c|c|}
\hline Location & Land area & $\begin{array}{l}\text { Number } \\
\text { of plant } \\
\text { species }\end{array}$ & $\begin{array}{l}\text { Plant species } \\
\text { density }\end{array}$ & $\begin{array}{l}\text { Endemic } \\
\text { species }\end{array}$ \\
\hline & $1000 \mathrm{~km}^{2}$ & & $\# / 1000 \mathrm{~km}^{2}$ & $\%$ \\
\hline \multicolumn{5}{|l|}{ Continental } \\
\hline California & 411 & 4,839 & 11.8 & 29.3 \\
\hline NE U.S. + Canada & 3,238 & 4,425 & 1.4 & 13.5 \\
\hline Texas & 751 & 4,196 & 5.6 & 9.0 \\
\hline Alaska & 1,479 & 1,366 & 0.9 & 5.9 \\
\hline \multicolumn{5}{|l|}{ Insular } \\
\hline Hawaii & 17 & 1,897 & 111.6 & 92.3 \\
\hline Galapagos & 8 & 701 & 87.6 & 25.0 \\
\hline Great Britain & 308 & 1,443 & 4.7 & 17.0 \\
\hline
\end{tabular}

"This table does not include the number of native subspecies or varieties, cultivated species, weeds or nonvascular plants (e.g. mosses, algae) .

Source: Raven and Axelrod (1978), Hickman (1993)

TABLE 2. More than $25 \%$ of California's native flora is extinct, endangered or of limited distribution

\begin{tabular}{lcccc}
\hline \hline & $\begin{array}{c}\text { Presumed } \\
\text { extinct }\end{array}$ & $\begin{array}{c}\text { Rare or } \\
\text { endangered }\end{array}$ & $\begin{array}{c}\text { Of limited } \\
\text { distribution }\end{array}$ & Total \\
\hline $\begin{array}{l}\text { Total California plant species, } \\
\text { subspecies, varieties }\end{array}$ & 34 & 1,129 & 532 & 1,695 \\
$\%$ of native flora & 0.5 & 17.9 & 8.4 & 26.3 \\
\hline
\end{tabular}

- includes 272 taxa that are rare or endangered in California but may be more common elsewhere Source: Skinner and Pavlik (1994).

Note: This table includes native species, subspecies and varieties of vascular plants. 


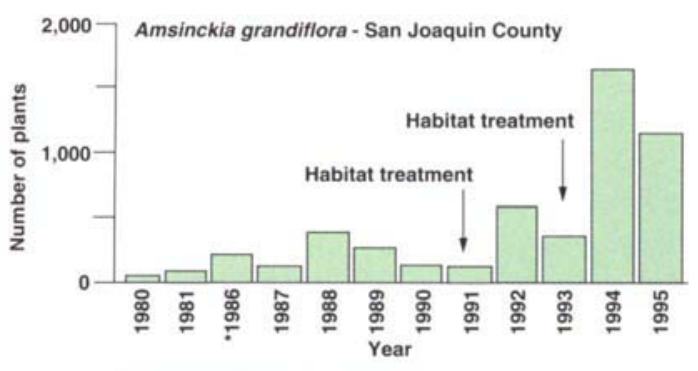

-Data not available for 1982-1985

Fig. 1. We are learning how to prevent the extinction of natural populations of endangered plants. In the 1980s this depleted population of the large-flowered fiddleneck (Amsinckia grandiflora), known only from one locality in San Joaquin County), had between 23 and 350 individual plants. It was listed as endangered under the Endangered Species Act, which allowed recovery activities to take place. Experiments revealed that this population was declining due to competition with nonnative grasses. Habitat treatments, including use of a selective herbicide that reduced the competition (i.e., killed or inhibited the nonnative grasses), have allowed the population to grow to more than 1,100 individuals. Other treatments are being developed for maintaining the biological diversity of California's grasslands while improving sustainable productivity.

islands. For example, both the Hawaiian and Galapagos islands are rich in unusual plants. Plant species density and endemism are extremely high in the tropics, especially when compared to the temperate British Isles. Botanists have concluded that the varied climate, soils, topography, and geological history of California have allowed the rapid evolution or long-term persistence of unique plants in our flora. It has been called an "island" due to its isolation from the rest of North America by the Cascade-SierraPeninsula mountains.

\section{Flora disappearing}

California is not only a great place for plants, it is also a great place for people. There are more than 30 million of our own species living here today and continued population growth is forecast. The growing human population has many resource needs, most of which are derived from the intensive use of land. Vast tracts of natural communities have been converted into farms, orchards and grazing lands.
This land conversion led to the emergence of a mighty, multibillion dollar agricultural economy as well as commercial and residential development on a grand scale. While we have all benefited from the strong, land-based California economy, this growth has come at the expense of wild landscapes that once housed a rich assemblage of native species

By the late 1960s it became had become clear that some species in the California flora were rarely encountered by field botanists. Some of these species may have been naturally rare, occupying small islands of habitat or comprising sparse populations that had evolved relatively recently (that is, over thousands, rather than millions, of years). But other species had not been naturally rare. These were being made rare because large, widespread populations were destroyed or marooned by human activities. Plant evolutionist G.L. Stebbins began keeping track of rare plants in a card file, and urged members of the California Native Plant Society (CNPS) to gather, compile and disseminate information on these fragile species. The first complete inventory of California's rare flora appeared in 1971 and included a simple, typewritten list of 520 species that were considered on the verge of extinction.

The fifth edition of the CNPS inventory was published in 1994, and it is widely regarded as the most thorough, scientifically defensible listing of rare plants worldwide. It was compiled and reviewed by hundreds of professional and amateur botanists after thousands of hours of field survey and careful documentation. No longer a simple list, the rare plant inventory is now available as a 338-page book or as a 3.8-megabyte computer database. Unfortunately, this growth and added sophistication were necessary for accurately tracking the rapid disappearance of California's native flora.

A total of 34 kinds of plants are thought to have gone extinct in California since collection records were begun late last century, including 28 entire species (table 2). The Los Angeles sunflower (Helianthus nuttallii ssp. parishii), for example, was a wetland plant with the ability to grow in saltladen soils. Losing this close relative of an important crop means the loss of valuable genes and gene combinations from our biotechnological toolbox. Some of the other species were only wildflowers, such as the diamond-petaled poppy (Eschscholzia rhombipetala), but their beauty and potential utility are probably gone forever. There is some uncertainty regarding extinction, because not every nook and cranny of habitat can be searched in a state as large and complex as California. Indeed, a few species that had been thought to be extinct have been rediscovered, sometimes by landowners who noticed a few unusual plants growing on a cliff or deep within a canyon on some remote part of their property. Nevertheless, most of these 34 kinds of plants with a uniquely California heritage will be counted among those whose long history abruptly ended in the 20th century.

Of even greater concern to scientists, however, is the large number of California plants that are in danger of becoming extinct in the wild (table 2). At least 1,129 kinds are regarded as rare or endangered, largely due to the impact of land development, motor vehicles, livestock grazing and exotic weeds. The rare or endangered list includes species of great economic importance, such as Monterey pine (Pinus radiata) (see sidebar), Northern California black walnut (Juglans californica var. hindsii ) and many wild relatives of onions, clovers, peas and beans. Most of these are native to lowelevation habitats such as grasslands, chaparral, oak woodland and coastal scrub that are rapidly being lost to suburban expansion. Another 532 kinds of plants were once considered widespread, but now have very limited distributions that are increasingly fragmented by roads, fields, and housing tracts. Overall, the rapid transformation from natural to industrialized landscapes now threatens more than $25 \%$ of the native flora with extinction.

\section{Conserving plant diversity}

Over the last century we have come to appreciate the diversity, utility and beauty of the California flora. As the 
human population grows and resource demands increase, the rates of species extinction and endangerment will rise dramatically. The concern of many scientists is not just the loss of species, but the losses of both the genes those species contain and the natural habitats where those species live. The genes have great potential for applications in agriculture, industry and medicine, while the habitats have pro- vided soil, water and wildlife as well as living laboratories for scientific inquiry. Therefore, actions taken to conserve plant diversity must adopt the wider perspective of conserving genes, species, and habitats in order to maintain the true heritage of the California flora.

Given the fact that a single plant species can contain thousands of genes, it is not practical to conserve every gene in the California flora. Instead, efforts are being made to identify situations (habitats, species, places) in which unusual genes are likely to occur. Those unusual or variant genes, perhaps coding for salt tolerance or fungal resistance, contribute to a pattern of genetic variation that can be mapped for a given region of the state. Ideally, the geographic patterns of genetic variation for many

Native California plants of great utility

These are selected examples that do not include species whose natural populations are harvested directly (e.g., wildland forestry, mushrooms), species of importance to Native Americans, or species with scientific, horticultural or landscaping applications.

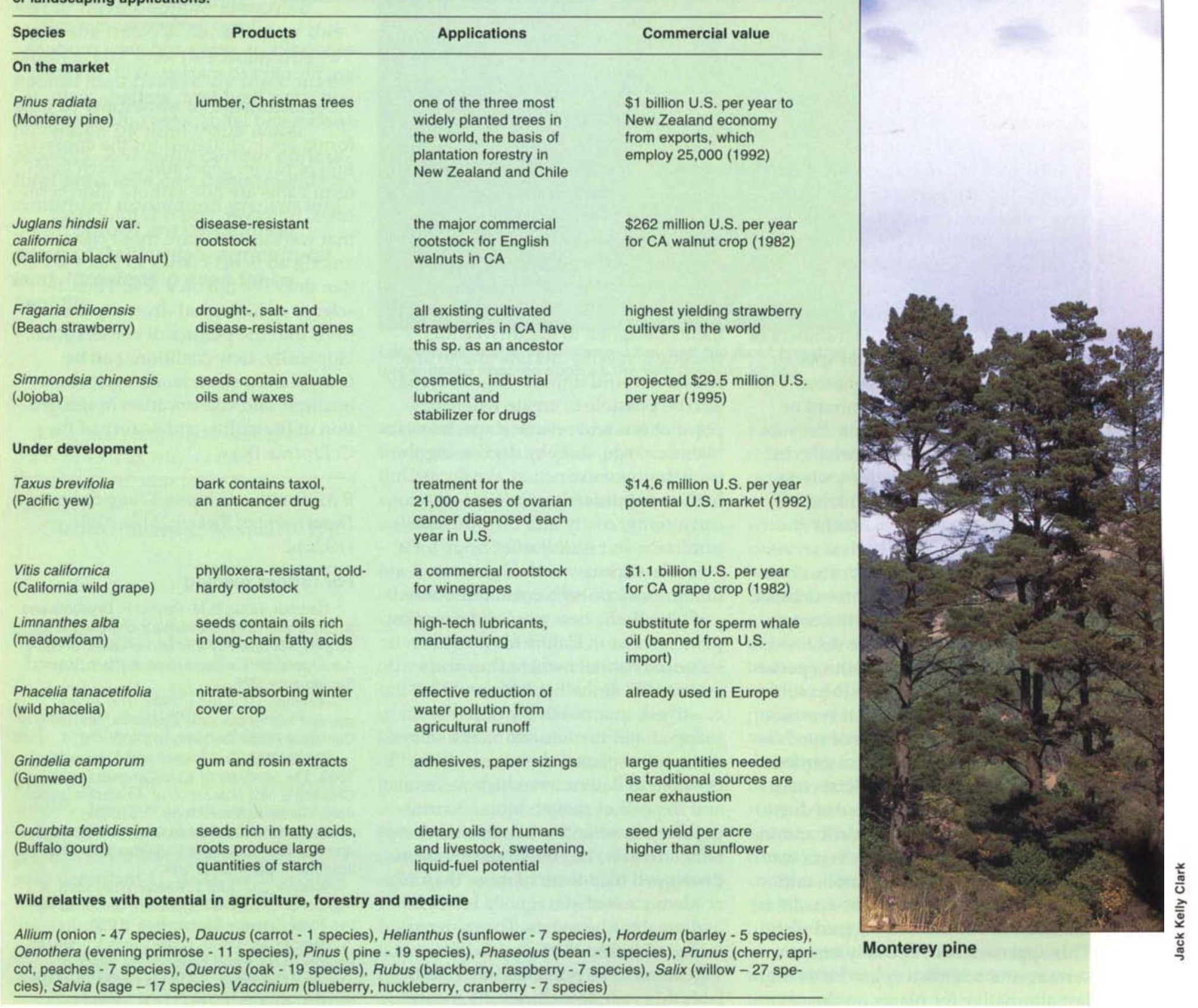


plants may coincide, as they do for forest trees in the Sierra Nevada. This would allow scientists and land managers to choose genetically rich or unusual habitats for conservation or special management practices (such as prescribed fire or seasonal grazing). However, although rapid progress has been made in developing the technology for assessing genetic variation in plants, it has not yet been widely applied and we do not have a clear picture of where the variant genes reside in our flora or within California's many landscapes.

A similar approach is being explored for identifying places in the state that have high concentrations of native species. The geographic distributions of plant habitats can be computer-mapped to show where there are overlapping pockets of favorable ecological conditions that are not within the boundaries of existing parks and wildlife reserves. Some of these pockets contain large numbers of both rare and common plant species and, if protected, would conserve more species for a given amount of money. Cost is a crucial issue because most new reserves would need to be established at low elevations where rare plants are plentiful but land values are high. The establishment and proper management of such reserves would also avoid the high costs of restoration, since it is cheaper to conserve intact habitats than to restore component species once they have declined.

But what can be done about species that are already endangered? In some cases there is so little habitat remaining that we can only conserve seeds in cold storage or in a botanical garden. However, under such artificial conditions, genetic variability erodes due to artificial selection, genetic drift and inbreeding. In addition, there is no way of conserving insect pollinators and other organisms that may be crucial to the existence of the endangered plant. This approach is both costly and uncertain, and scientists regard it as the last alternative for plants on the very

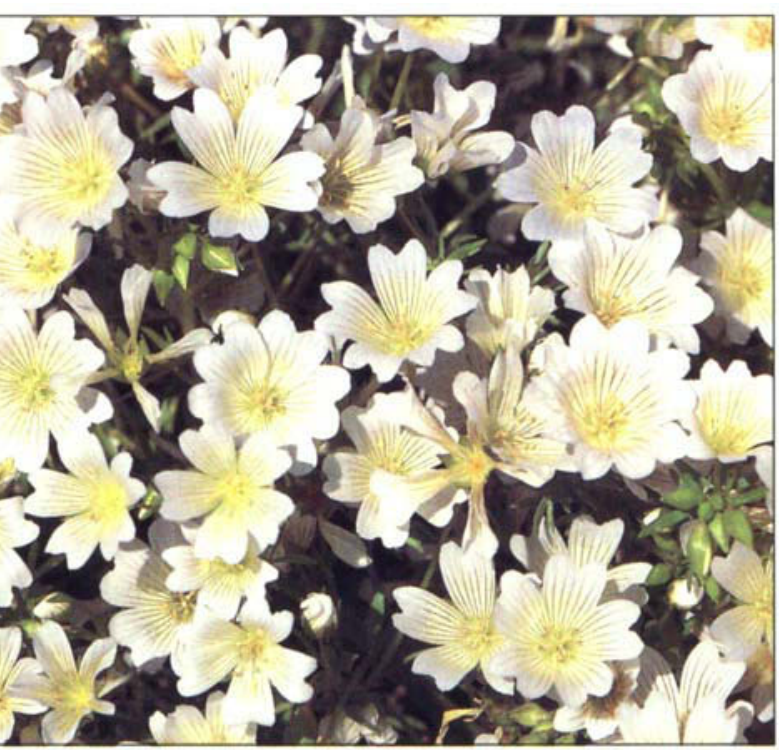

Seeds from meadowioam (Limnanthes alba) provide oils for high-tech lubricants. (Photograph by Mark W. Skinner/California Native Plant Society)

edge of oblivion. However, this method has been applied to restoring endangered plants to the wild when sufficient habitat remains. For example, stored seeds have been used to replace rare torrey pines near San $\mathrm{Di}$ ego after ips beetles threatened the only mainland population. Stored seeds can also be used for field experiments designed to identify factors causing a species' decline and to ameliorate harmful impacts (fig. 1). It may also be possible to create whole new populations and restore a species to its historic range, thereby decreasing the probability of extinction. Again, such high-tech intervention is time-

consuming, costly and the outcome is uncertain, but it may offer hope for a few select species with high conservation priority or high economic value.

Overall, the best way of conserving plant species in California is to conserve the habitats where they thrive and evolve. If the habitats could be classified, quantitatively described, mapped and inventoried in the same manner as species, then it would be possible to determine which were rare and in need of conservation. A comprehensive, scientific classification system, however, has only recently been developed by a team of more than 25 academic scientists, agency biologists and amateur botanists. The system is included in The Manual of California Vegetation to be published by CNPS later this year. It includes diagnostic keys to more than 235 plant habitats throughout California, allowing for identification in the field. Although many more data need to be gathered, it is likely that the California system will become a model for habitat conservation efforts throughout the world.

\section{New coalitions needed}

Preserving the diversity of the California flora is in our own best interests. With diversity will come long-term economic gain, especially as genes and gene products are brought to market. With diversity will come long-term aesthetic gain, as species and landscapes unique to California are maintained for the appreciation of future generations. Such longterm gains are not without short-term costs, however, and it is important that we learn to share those costs among all beneficiaries so that the burden does not fall on a few. Thus, the science of biological diversity transitions into the politics of conservation. Hopefully, new coalitions can be formed between science, agriculture, business and conservation in recognition of the utility and beauty of the California flora.

B.M. Pavlik is Gibbons-Young Professor, Department of Biology, Mills College, Oakland.

\section{For further reading}

Barbour, M.G., B.M. Pavlik, F. Drysdale and S. Linstrom. 1993. California's changing landscapes: the diversity and conservation of California vegetation. California Native Plant Society, Sacramento. 225.

Hickman, J.C., (ed.). 1993. The Jepson manual: higher plants of California. University of California Press, Berkeley. p 1400.

Pavlik, B.M., D. Nickrent and A. Howald. 1993. The recovery of an endangered plant I. Creating a new population of Amsinckia grandiflora. Conservation Biology. 7 : 510-26.

Raven, P.H. and D.I. Axelrod. 1978. Origin and relationships of the California flora. UC Publications in Botany. 72: 134.

Sawyer, J.O. and T. Keeler-Wolf. 1995. A manual of California vegetation. California Native Plant Society, Sacramento. p 250.

Skinner, M. and B. Pavlik., (eds.). 1994. Inventory of Rare and Endangered Vascular Plants of California. California Native Plant Society, Sacramento. p 338 . 